\section{Impact of birth weight and daily weight gain during suckling on the weight gain of weaning piglets}

[Impacto do peso ao nascimento e ganho de peso na maternidade sobre o ganho de peso dos leitões na creche]

D. Surek ${ }^{1}$, L.M. Almeida ${ }^{1}$, J.C. Panisson ${ }^{1}$, E.L. Krabbe ${ }^{3}$, S.G. Oliveira ${ }^{2}$, G.C. Alberton ${ }^{2}$, A. Maiorka ${ }^{2}$

\author{
${ }^{1}$ Programa de pós-graduação - Universidade Federal do Paraná - Curitiba, PR \\ ${ }^{2}$ Universidade Federal do Paraná - Curitiba, PR \\ ${ }^{3}$ Centro Nacional de Pesquisa em Suínos e Aves - Concórdia, SC
}

https://orcid.org/0000-0002-7520-058X S. G. Oliveira

https://orcid.org/0000-0002-2913-1173 G.C. Alberton

https://orcid.org/0000-0001-6220-092X A. Maiorka

https://orcid.org/0000-0001-5468-7731

\begin{abstract}
This study evaluated the effect of birth weight and weight gain during the suckling phase on the piglet daily weight gain during the nursery phase $(21-61$ days of age). Piglets $(n=534)$ derived from 55 first-parity sows were weighed at birth, weaning, and end of the nursery phase. The data were analyzed according to a completely randomized experimental design, with three classes of birth weight (BW) and two classes of weight gain during the suckling phase (SDWG). High BW and low SDWG piglets were $0.2 \mathrm{~kg}$ lighter at weaning than low BW and high SDWG animals $(\mathrm{P}<0.05)$. However, at the end of the nursery phase, this situation was inverted, with high $\mathrm{BW}$ and low SDWG piglets $2.20 \mathrm{~kg}$ heavier $(\mathrm{P}<0.05)$. Low BW and high SDWG piglets were heavier at weaning and at the end of the nursery phase than low BW and low SDWG piglets $(\mathrm{P}<0.05)$. At the same time, intermediate and high BW and low and high SDWG piglets presented body weight differences at weaning $(\mathrm{P}<0.05)$, but not at the end of the nursery phase $(\mathrm{P}<0.05)$. Piglets with 1.25 to $2.30 \mathrm{~kg} \mathrm{BW}$ and low weight gain during suckling presented a partial compensatory growth during the nursery phase.
\end{abstract}

Keywords: pigs, compensatory gain, lactation, primiparous

\title{
RESUMO
}

Objetivou-se avaliar o efeito do peso dos leitões ao nascimento e do seu ganho de peso na maternidade sobre seu desempenho na fase de creche (21-61 dias de idade). Quinhentos e trinta e quatro leitões, provenientes de 55 primíparas, foram pesados ao nascimento, no desmame e na saída da creche. Os animais foram distribuídos em um delineamento inteiramente ao acaso, em três classes de peso ao nascimento (PN) e duas classes de ganho de peso diário (GPD) na maternidade. Os animais com alto PN e baixo GPD na maternidade desmamaram $0,2 \mathrm{~kg}$ mais leves que os animais com baixo PN e alto GPD na maternidade $(P<0,05)$. Porém, os animais com alto PN e baixo GPD na maternidade saíram da creche 2,10kg mais pesados $(P<0,05)$. A diferença aos 21 dias entre os dois tratamentos (alto e baixo GPD) com animais de baixo PN foi de 1,18kg e passou para $2,20 \mathrm{~kg}$ ao final da creche $(P<0,05)$. No caso dos animais com médio e alto PN, a diferença ao desmame era de 1,14 e 1,26kg e passou para 0,90 e 0,70kg na saída da creche $(P<0,05)$, respectivamente. Leitões com peso ao nascimento entre 1,25 e 2,30kg, com baixo ganho de peso diário na maternidade, apresentaram efeito compensatório parcial no ganho de peso diário durante a creche.

Palavras-chave: suínos, ganho compensatório, lactação, primípara

\section{INTRODUCTION}

Several factors influence piglet performance after birth. In general, pig producers aim at heavy birth and weaning weights because they are associated with better performance during subsequent rearing phases. This association was first described in the 1980s by Powell and Aberle
(1980) and has been recently studied and discussed in the literature. However, Surek et al. (2014), working with litters of 11 piglets each standardized by birth weight, observed that lighter piglets presented a lighter weaning weight, but had the same daily weight gain as heavier piglets during the suckling phase.

Recebido em 3 de maio de 2018

Aceito em 6 de maio de 2019

*Autor para correspondência (corresponding author)

E-mail: amaiorka@ufpr.com 
Sow milk production and milk intake by piglets determine their early performance. Harrell et al.(1993) verified that piglets fed an artificial diet grew, on average, $70 \%$ faster and were $53 \%$ heavier at 21 days of age when compared to those remaining with the sow, suggesting that sow milk production did not supply all the nutritional requirements of piglets. According to Boyd et al. (1995), a sow rearing 10 piglets up to 21 days old should produce $18-20 \mathrm{~kg}$ of milk per day. However, modern hyperprolific sows can produce only $1 \mathrm{~kg}$ of milk per piglet in litters with up to 14 piglets (Auldist et al., 1998). Therefore, piglets may experience nutritional restriction during suckling and consequently present a low daily weight gain. The genetic potential for daily weight gain can only be expressed if animals have access to the required amount of nutrients. Fraser and Morley Jones (1975) found that heavier piglets at birth and at three weeks of age tended to occupy the more productive teats, but this relation was considered weak due to the low correlation coefficient. Kim et al. (2000) observed in primiparous sows that piglets suckling anterior and middle teats presented a higher daily weight gain than those suckling posterior teats, but no preference of the heavy piglet for anterior teats was detected.

Therefore, the study of the relationship of body weight of pigs at different rearing phases and submitted to different environmental conditions and nutritional and non-nutritional strategies may allow the design of management practices to improve live performance, pig livability, and carcass quality. Therefore, the aim of this research was to study the relationship between the birth weight of piglets and daily weight gain during suckling with their daily weight gain during the nursery phase.

\section{MATERIAL AND METHODS}

The experiment was approved by the Committee of Ethics on Animal Use of the sector of Agricultural Sciences of the Federal University of Paraná, Curitiba, PR, Brazil, under protocol number 072. Historical data from a commercial farm located in the south of Brazil, state of Paraná, were analyzed between January and March 2009. Five hundred and thirty-four piglets born from 55 primiparous sows (Landrace $\mathrm{x}$ Large White) during the same week were evaluated. Piglet sex and individual birth weight
(BW) were recorded. Approximately six hours after the placental expulsion, litters were standardized as a function of the number of functional teats. After litter standardization, piglets were submitted to teeth clipping and tail docking. Males were castrated at 5 days of age.

Sows were housed in individual farrowing crates $(2.2 \times 1.6 \mathrm{~m})$ on fully-slatted plastic floor and equipped with a $5-\mathrm{kg}$ capacity concrete trough feeder and a cup drinker. A micro-pelleted diet was manually offered to the sows four times daily, at ad libitum allowance. Piglets were supplied with creep feed after 5 days of age. Room environment was controlled using sidecurtains. Piglet creep area was heated using incandescent lamps. All piglets were weighed at weaning in order to calculate the weaning weight adjusted for 21 days (WW21), according to Favero et al. (1992), and average daily weight gain during the suckling phase (SDWG). Weaning weight was adjusted to 21 days using the following linear regression equation: $Y=Z-$ $b(X-21)$, where: $\mathrm{Y}=$ adjusted weight; $\mathrm{Z}=$ observed weight; $b=$ coefficient of linear regression of weaning weight; and $\mathrm{X}=$ age at weaning.

At weaning, piglets were transferred to a nursery room, where they were maintained for 40 days. A four-phase feeding program was applied, consisting of three pre-starter diets (1, 2, and 3) and a starter diet. Pre-starter diet 1 was supplied during the suckling phase and first nursery week. Pre-starter diets 2 and 3 were pelleted and supplied during weeks 2 and 3 of the nursery period, respectively. Starter diet was pelleted and supplied during the last 19 days of the study. Diets were based on corn and soybean meal, and dairy products were gradually reduced until their total withdrawal in the starter diet. Sow and piglet diets were formulated to supply their nutritional requirements according to Rostagno et al. (2005).

All piglets were weighed at the end of the nursery phase in order to calculate the body weight adjusted for 61 days of age (LW61), according to Favero et al. (1992), and average daily weight gain during the nursery phase (NDWG). Nursery weight was adjusted to 61 days of age using the following linear regression equation: $Y=Z-b(X-61)$, where: $\mathrm{Y}=$ adjusted weight; $Z=$ observed weight; $b=$ coefficient of 
linear regression of nursery weight; and $\mathrm{X}=$ age at weighing. Piglets were classified for data analysis into three birth weight $(\mathrm{BW})$ classes (by dividing the group into $1 / 3$ low, $1 / 3$ intermediate, and $1 / 3$ high) and two pre-weaning performance classes (by dividing the group into $1 / 2$ high or low daily weight gain during the suckling phase - SDWG), as follows: low BW and low SDWG piglets, low BW and high SDWG piglets, intermediate $\mathrm{BW}$ and low SDWG piglets, intermediate BW and high SDWG piglets, high BW and low SDWG piglets, and high BW and high SDWG piglets.

Performance data were analyzed according to a completely randomized experimental design. Initially, three treatments were evaluated (three birth weight classes), with 178 replicates (piglets) per treatment. Subsequently, six treatments were evaluated, consisting of three birth weight classes and two pre-weaning weight gain classes per birth weight, with 89 replicates (piglets) per treatment. Firstly, the data were submitted to the Shapiro-Wilk normality test. The data with normal distribution were analyzed using ANOVA. Means were compared by the Tukey's test at $5 \%$ probability level. Correlations between treatments as a whole and a function of birth weight classes were analyzed by the Pearson method.

\section{RESULTS}

The average birth weight of the 534 piglets was $1.43 \mathrm{~kg}$, ranging between 0.60 and $2.30 \mathrm{~kg}$.
Weaning age ranged between 18 and 25 days, with an average of 21.3 days. The correlations among performance traits of the 534 piglets are shown in Table 1. All the analyzed traits (BW, WW21, SDWG, LW61, and NDWG) were positively correlated. $\mathrm{BW}$ and WW21 were highly correlated with LW61, and BW presented a higher correlation with NDWG than with SDWG.

Piglet performance results from birth to the end of the nursery phase per BW class are shown in Table 2. Low, intermediate, and high birth weight classes included piglets weighing 0.60 to $1.25,1.25$ to 1.50 , and 1.50 to $2.30 \mathrm{~kg}$, respectively. The initial difference of $0.65 \mathrm{~kg}$ between the average BW of piglets of low and high BW classes resulted in differences of $18 \mathrm{~g}$ in SDWG, $1010 \mathrm{~g}$ in WW21, $61 \mathrm{~g}$ in NDWG, and $3500 \mathrm{~g}$ in LW61 (Table 2).

Correlations among the evaluated parameters (BW, WW21, SDWG, LW61, and NDWG) as a function of BW class are shown in Table 3 . There was no correlation between $\mathrm{BW}$ and SDWG for any of the BW classes. There was no correlation between BW and LW61 or between $\mathrm{BW}$ and NDWG in intermediate BW piglets. No correlations between WW21 and NDWG or between SDWG and NDWG were detected in piglets of intermediate and high $\mathrm{BW}$ classes, or between BW and WW21 in high BW piglets. The remaining correlations were positive and significant (Table 3).

Table 1. Coefficient of correlation between piglet birth weight, daily weight gain during suckling, weaning weight, daily weight gain during the nursery phase and live weight at the end of the nursery phase

\begin{tabular}{lllll} 
& & \multicolumn{2}{c}{ All piglets } & \\
& $\mathrm{BW}$ & $\mathrm{WW} 21^{2}$ & $\mathrm{SDWG}^{3}$ & \\
\hline $\mathrm{WW}^{1} 1^{2}$ & $0.50^{* *}$ & & & \\
$\mathrm{SDWG}^{3}$ & $0.18^{* *}$ & $0.94^{* *}$ & & \\
$\mathrm{LW}^{4}$ & $0.50^{* *}$ & $0.48^{* *}$ & $0.35^{* *}$ & \\
$\mathrm{NDWG}^{5}$ & $0.40^{* *}$ & $0.24^{* *}$ & $0.11^{* *}$ & $0.97 * *$ \\
\hline
\end{tabular}

** P-value < 0.01. ${ }^{1}$ Birth weight. ${ }^{2}$ Weaning weight corrected for 21 days. ${ }^{3}$ Daily weight gain during suckling corrected for WW21. ${ }^{4}$ Live weight at the end of the nursery phase corrected for 61 days. ${ }^{5}$ Daily weight gain during the nursery phase corrected for WW21 and LW61. 
Table 2. Effect of piglet birth weight classes (low, intermediate, and high) on daily weight gain during suckling, weaning weight, daily weight gain during the nursery phase, and live weight at the end of the nursery phase

\begin{tabular}{|c|c|c|c|c|c|}
\hline & $\mathrm{BW},{ }^{1} \mathrm{~kg}$ & SDWG,$^{2}$ g.d ${ }^{-1}$ & $\mathrm{WW} 21,{ }^{3} \mathrm{~kg}$ & NDWG,${ }^{4}$ g.d ${ }^{-1}$ & $\mathrm{LW} 61,{ }^{5} \mathrm{~kg}$ \\
\hline Low BW ${ }^{1}$ & $1.11 \pm 0.16$ & $190 \pm 35^{b}$ & $5.10 \pm 0.76^{\mathrm{c}}$ & $286 \pm 70^{c}$ & $16.5 \pm 3.1^{\mathrm{c}}$ \\
\hline Intermediate $\mathrm{BW}^{1}$ & $1.44 \pm 0.07$ & $201 \pm 33^{\mathrm{a}}$ & $5.65 \pm 0.71^{\mathrm{b}}$ & $313 \pm 60^{\mathrm{b}}$ & $18.2 \pm 2.5^{\mathrm{b}}$ \\
\hline High BW $^{1}$ & $1.76 \pm 0.14$ & $208 \pm 37^{\mathrm{a}}$ & $6.11 \pm 0.78^{\mathrm{a}}$ & $347 \pm 77^{\mathrm{a}}$ & $20.0 \pm 3.2^{\mathrm{a}}$ \\
\hline P-value & & 0.01 & 0.01 & 0.01 & 0.01 \\
\hline $\mathrm{CV}$ & & 17.68 & 13.40 & 22.05 & 16.16 \\
\hline
\end{tabular}

${ }^{a-c}$ Means \pm SEM followed by different letters in the same column are statistically different $(\mathrm{P}<0.05)$.

${ }^{1}$ Birth weight. ${ }^{2}$ Daily weight gain during suckling corrected for body weight at weaning with 21 days of age. ${ }^{3}$ Weaning weight corrected for 21 days. ${ }^{4}$ Daily weight gain during the nursery phase corrected for WW21 and live weight at the end of the nursery phase (61 days). ${ }^{5}$ Live weight at the end of the nursery phase corrected for 61 days.

Table 3. Coefficient of correlation between piglet birth weight, daily weight gain during suckling, weaning weight, daily weight gain during the nursery phase, and live weight at the end of the nursery phase according to birth weight classes (low, intermediate, and high)

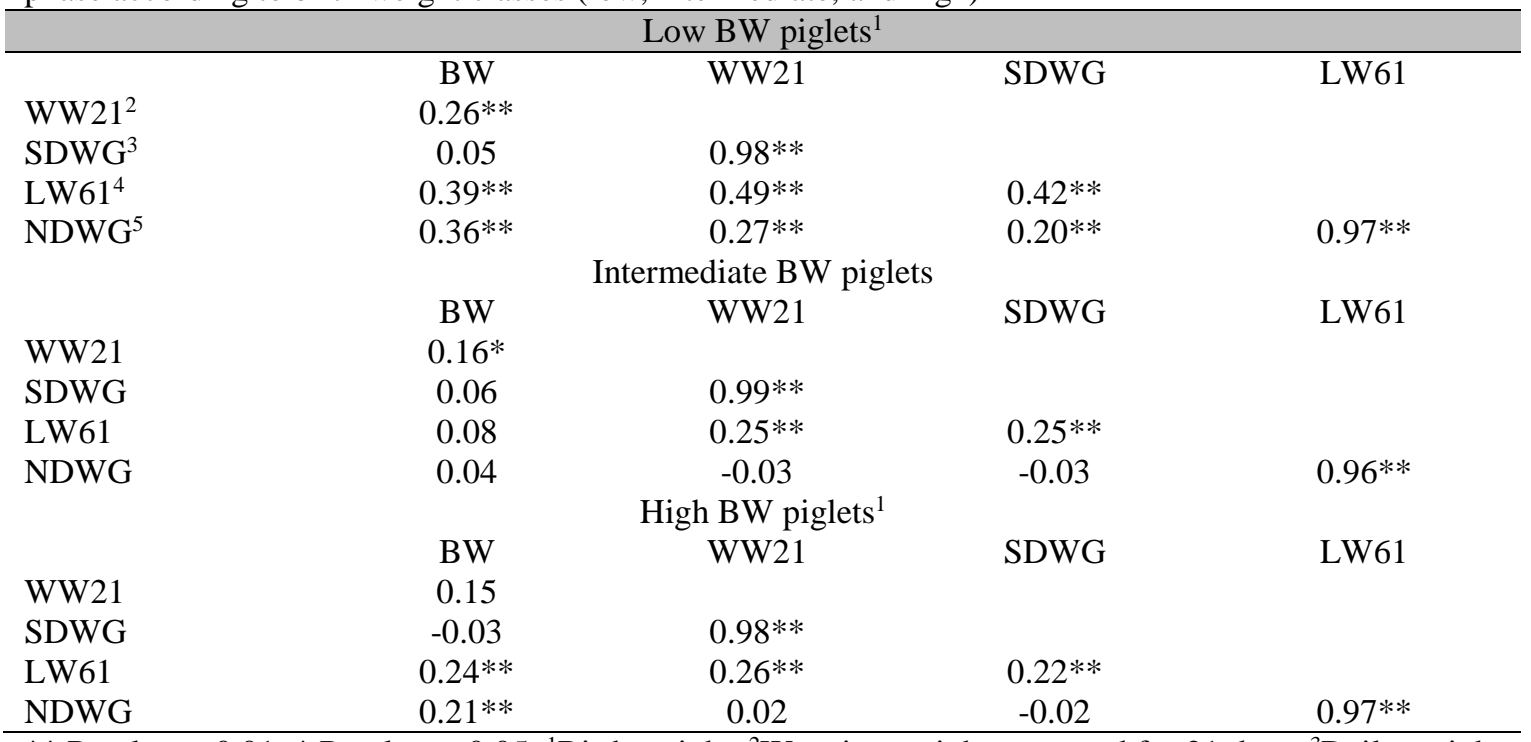

** P-value $<0.01 ; *$ P-value $<0.05 .{ }^{1}$ Birth weight. ${ }^{2}$ Weaning weight corrected for 21 days. ${ }^{3}$ Daily weight gain during suckling corrected for WW21. ${ }^{4}$ Live weight at the end of the nursery phase corrected for 61 days. ${ }^{5}$ Daily weight gain during the nursery phase corrected for WW21 and LW61.

The analysis of the effects of high and low SDWG, within BW classes (Tab. 4) demonstrated that high SDWG piglets presented higher WW21. Body weight difference in low BW and low SDWG piglets was $1.18 \mathrm{~kg}$ at 21 days and increased to $2.20 \mathrm{~kg}$ at the end of the nursery phase. Intermediate and high BW piglets presented weight differences of 1.14 and $1.26 \mathrm{~kg}$ at weaning and 0.90 and $0.70 \mathrm{~kg}$ at the end of the nursery phase, respectively. High BW and low SDWG piglets were $0.2 \mathrm{~kg}$ lighter at weaning when compared with those with low BW and high SDWG. However, this situation was inverted at the end of the nursery phase, when high BW and low SDWG piglets were $2.10 \mathrm{~kg}$ heavier when compared to those with low BW and high SDWG. In number of piglets from high BW and low SDWG groups, among the 89 animals, 48 piglets had a weaning weight below $5.69 \mathrm{~kg}$, which was the mean weaning weight of the low BW and high SDWG group. In addition, among these same 48 piglets, 29 animals at the end of the nursery phase exceeded $17.6 \mathrm{~kg}$ of weight, which was the mean weight achieved by the low BW and high SDWG group. 
Table 4. Effect of piglet birth weight classes (low, intermediate, and high) and daily weight gain during suckling (low or high) on weaning weight, daily weight gain during the nursery phase, and live weight at the end of the nursery phase

\begin{tabular}{|c|c|c|c|c|c|c|}
\hline & & $\mathrm{BW},{ }^{1} \mathrm{~kg}$ & $\begin{array}{l}\text { SDWG, }{ }^{2} \\
\text { g.d } \text { d }^{-1}\end{array}$ & $\mathrm{WW} 21,{ }^{3} \mathrm{~kg}$ & $\mathrm{NDWG}^{4}{ }^{4} \mathrm{~g} \cdot \mathrm{d}^{-1}$ & $\mathrm{LW} 61,{ }^{5} \mathrm{~kg}$ \\
\hline $\mathrm{BW}^{1}$ & $\mathrm{SDWG}^{2}$ & & & & & \\
\hline \multirow{2}{*}{ Low } & Low & $1.10 \pm 0.19$ & $162 \pm 24$ & $4.51 \pm 0.53^{f}$ & $274 \pm 70^{\mathrm{d}}$ & $15.4 \pm 2.9^{\mathrm{d}}$ \\
\hline & High & $1.11 \pm 0.14$ & $218 \pm 19$ & $5.69 \pm 0.42^{\mathrm{c}}$ & $298 \pm 68^{\mathrm{cd}}$ & $17.6 \pm 2.8^{c}$ \\
\hline \multirow{2}{*}{ Intermediate } & Low & $1.44 \pm 0.07$ & $174 \pm 23$ & $5.08 \pm 0.48^{\mathrm{e}}$ & $315 \pm 58^{\mathrm{bc}}$ & $17.7 \pm 2.4^{\mathrm{c}}$ \\
\hline & High & $1.44 \pm 0.07$ & $228 \pm 17$ & $6.22 \pm 0.37^{b}$ & $310 \pm 63 b^{c}$ & $18.6 \pm 2.5^{\mathrm{bc}}$ \\
\hline \multirow{2}{*}{ High } & Low & $1.76 \pm 0.15$ & $177 \pm 22$ & $5.49 \pm 0.48^{\mathrm{d}}$ & $354 \pm 78^{\mathrm{a}}$ & $19.7 \pm 3.3^{\mathrm{ab}}$ \\
\hline & High & $1.75 \pm 0.13$ & $238 \pm 21$ & $6.75 \pm 0.45^{\mathrm{a}}$ & $340 \pm 76^{\mathrm{ab}}$ & $20.4 \pm 3.1^{\mathrm{a}}$ \\
\hline P-value & & & & 0.01 & 0.01 & 0.01 \\
\hline $\mathrm{CV}$ & & & & 8.13 & 21.96 & 15.73 \\
\hline
\end{tabular}

${ }^{\mathrm{a}-\mathrm{f}}$ Means followed by different letters in the same column are statistically different $(\mathrm{P}<0.05)$.

${ }^{1}$ Birth weight. ${ }^{2}$ Daily weight gain during suckling corrected for WW21. ${ }^{3}$ Weaning weight corrected for 21 days. ${ }^{4}$ Daily weight gain during the nursery phase corrected for WW21 and LW61. ${ }^{5}$ Live weight at the end of the nursery phase corrected for 61 days.

\section{DISCUSSION}

The correlation between piglet birth weight and their subsequent performance has been extensively reported in the literature. Gondret $e t$ al. (2006), Beaulieu et al. (2010), and Fix et al. (2010) observed a positive correlation between birth weight and post-weaning weight gain and body weight, which continues up to market age. Surek et al. (2014) found that heavier piglets at birth were also heavier at weaning. However, these authors did not observe a correlation between birth weight and daily weight gain during suckling and attributed this result to the litter birth weight equalization.

Wolter et al. (2002), using litters standardized by birth weight and classified as light or heavy (1.3 vs. $1.8 \mathrm{~kg}$ ), obtained a $0.9-\mathrm{kg}$ difference in weaning weight between birth weight classes, and the same difference in piglets fed or not a liquid supplement during suckling. In addition, supplementation during suckling increased piglet weight gain by $23 \%$, but no effect of birth weight was detected. The authors also found that supplementation during lactation resulted in higher weaning weights for heavier piglets at birth and suggested that supplementation should only be provided to low birth weight piglets in order to obtain less variation in weaning weight.

When comparing the different BW classes in the present study, there was a low BW x WW21 correlation in intermediate BW piglets, and this correlation was not significant in high BW animals. Quiniou et al. (2002) performed a polynomial regression analysis of the relationship between birth weight and weaning weight and found that for each additional $100 \mathrm{~g}$ in birth weight of piglets with approximately $1 \mathrm{~kg}$, there was a $400 \mathrm{~g}$ increase in weaning weight, while in $2 \mathrm{~kg}$ birth weight piglets, the increase in weaning weight was only $200 \mathrm{~g}$.

The data in Tables 1 and 2 show that low BW piglets continued to be lighter at weaning. However, when piglets are considered within birth weight classes, this relationship does not apply. The present study showed that low BW piglets might have presented higher weaning weight corrected for 21 days than those with high BW. The causes of this variation in SDWG were not evaluated once several factors can influence daily weight gain during suckling, such as genetics, colostrum and creep feed intake, differences in milk production among sows and teats, as well as health conditions. However, regardless of the causes, the results allow an interesting reflection on the growth behavior of piglets during the subsequent nursery phase.

The current results indicate a partial compensatory gain in the nursery by intermediate and high BW and low SDWG piglets. Fix et al. (2010) evaluated the performance of piglets removed or not from their biological dams and found an interaction between birth weight and piglet transference. The non-fostered heavy BW 
piglets presented higher daily weight gain during suckling and weaning weight when compared to fostered piglets. However, this interaction was not observed in subsequent phases. Fix et al. (2010) suggested that cross-fostered piglets were able to overcome their initial disadvantage.

Sarkar et al. (1983), working with the removal of piglets from dams at regular intervals in order to force feed restriction, found a $6.3 \mathrm{~kg}$ difference in weaning weight (35 days) between the control and restricted-fed piglets, but this difference was only $6 \mathrm{~kg}$ at 166 days of age. Wolter et al. (2002) did not find any interaction between birth weight and liquid supplementation of suckling piglets relative to their performance immediately after weaning or until they reach $25 \mathrm{~kg}$ of live weight. However, between 14 and $25 \mathrm{~kg}$, light BW piglets not supplemented during suckling presented a higher feed efficiency and weight gain than other treatments (unsupplemented or supplemented $v s$. light or heavy). These authors suggested that further studies on the causes of this interaction are needed and observed a higher influence of birth weight on post-weaning performance and days to market than the supplementation during the suckling period. Miller et al. (2012) also did not observe any residual effect of feeding a liquid supplement to suckling piglets on postweaning body weight. However, caution should be taken when analyzing the effects of liquid supplementation of suckling piglets because, according to Azain et al. (1996) and Miller et al. (2012), its supply during suckling is more effective in the summer, promoting higher weaning weights. Therefore, the adoption of management practices aiming at feed restriction of piglets during suckling should be economically assessed, including their performance during the subsequent phases.

\section{CONCLUSIONS}

In conclusion, within the same birth weight class, the daily weight gain during the nursery phase of piglets with low weight gain during suckling was not different when compared to those with a high weight gain. Piglets with $1.25-2.30 \mathrm{~kg}$ birth weight and low weight gain during suckling presented a partial compensatory growth, as shown by their body weight at the end of the nursery phase.

\section{REFERENCES}

AULDIST, D.E.; MORRISH, L.; EASON, P.; KING, R.H. The influence of litter size on milk production of sows. J. Anim. Sci., v.67, p.333337, 1998.

AZAIN, M.J.; TOMKINS, T.; SOWINSKI, J.S. et al. Effect of supplemental pig milk replacer on litter performance: seasonal variation in response. J. Anim. Sci., v.74, p.2195-2202, 1996.

BEAULIEU, A.D.; AALHUS, J.L.; WILLIAMS, N.H.; PATIENCE, J.F. Impact of piglet birth weight, birth order, and litter size on subsequent growth performance, carcase quality, muscle composition, and eating quality of pork. J. Anim. Sci., v.88, p.2767-2778, 2010.

BOYD, R.D.; KENSINGER, R.S.; HARRELL, R.J.; BAUMAN, D.E. Nutrient uptake and endocrine regulation of milk synthesis by mammary tissue of lactating sows. J. Anim. Sci., v.73, Suppl.2p.36-56, 1995.

FAVERO, J.A.; IRGANG, R.; COSTA, C.N. et $a l$. Fatores de ajuste de peso de suínos para 154 dias de idade. Rev. Soc. Bras. Zootec., v.21, p.683-690, 1992.

FIX, J.S.; CASSADY, J.P.; HOLL, J.W. et al. Effect of piglet birth weight on body weight, growth, backfat, and longissimus muscle area of commercial market swine. Livest. Sci., v.127, p.51-59, 2010.

FRASER, D.; MORLEY JONES, R. The 'teat order' of suckling pigs: I. Relation to birth weight and subsequent growth. J. Agric. Sci., v.84, p.387-391, 1975.

GONDRET, F.; LEFAUCHER, L.; JUIN, H. et $a l$. Low birth weight is associated with enlarged muscle fiber area and impaired meat tenderness of the longissimus muscle in pigs. J. Anim. Sci., v.84, p.93-103, 2006.

HARRELL, R.J.; THOMAS, M.J.; BOYD, R.D. Limitations of sow milk yield on baby pig growth. Proc. Cornell Nutr. Conf., p.156-164, 1993.

KIM, S.W.; HURLEY, W.L.; HAN, I.K.; EASTER, R.A. Growth of nursing pigs related to the characteristics of nursed mammary glands. $J$. Anim. Sci., v.78, p.1313-1318, 2000. 
MILLER, Y.J.; COLLINS, A.M.; SMITS, R.J. et al. Providing supplemental milk to piglets preweaning improves the growth but not survival of gilt progeny compared with sow progeny. $J$. Anim. Sci., v.90, p.5078-5085, 2012.

POWELL, S.E.; ABERLE, E.D. Effects of birth weight on growth and carcass composition of swine. J. Anim. Sci., v.50, p.860, 1980.

QUINIOU, N.; DAGORN，J.; GAUDRE，D. Variation of piglet's birth weight and consequences of subsequent performance. Livest. Prod. Sci., v.78, p.63-70, 2002.

ROSTAGNO, H.S.; ALBINO, L.F.T.; DONZELE, J.L. et al. Brazilian tables for poultry and swine: composition of feedstuffs and nutritional requirements. 2.ed. Viçosa: UFV, 2005. 181p.
SARKAR, N.K.; LODGE, G.A.; WILLIAMS, C.J.; ELLIOT, J.I. The effects of undernutrition of suckled pigs on subsequent growth and body composition after nutritional rehabilitation. $J$. Anim. Sci., v.57, p.34-42, 1983.

SUREK, D.; BARRILLI, L.N.E.; BUENO, I.J.M. et al. Growth of suckling piglets in litters standardized by weight. J. Anim. Sci., v.92, p.177-181, 2014.

WOLTER, B.F.; ELLIS, M.; CORRIGAN, B.P.; DEDECKER, J.M. The effect of birth weight and feeding of supplemental milk replacer to piglets during lactation on pre-weaning and postweaning growth performance and carcass characteristics. J. Anim. Sci., v.80, p.301-308, 2002. 